\title{
Topological vs. lexical determination in English particle verbs (PVs)
}

\author{
Renata Geld \\ geldrenata@gmail.com \\ University of Zagreb, Croatia
}

\begin{abstract}
The central aim of this work is to describe semantic determination, i.e., topological vs. lexical determination, by investigating aspects of construal (Langacker 1987) in English PVs with in and out. The paper focuses on L2 processing related to what we might call strategic thinking about linguistic meaning. More specifically, it attempts to demonstrate the following: a) how the nature of verbs affects the overall semantic determination of particle verb constructions, and b) if/how the users of English make sense of particle verbs, and how much they rely on topological/grammatical components in the process of constructing meaning. The results suggest that the nature of verbs does affect the users' strategic meaning construal - it differs in terms of their tendency towards one of the following types of semantic determination: a) topological, b) lexical, and, c) compositional.
\end{abstract}

Keywords: particle verbs, strategic construal, in, out, lexical, topological

\section{INTRODUCTION}

For the purpose of this paper, particle verbs (PVs) will be defined as those verb-plusparticle combinations in which the particle is semantically more closely linked with the verb and not with the noun that follows (see e.g. Biber et al. 2002, Cappelle 2002, 2005, Dehé 2002, Fraser 1970, Lindner 1981, Lipka 1972, Talmy 2000). The key condition for a word to be called a particle is that it is not being used as a preposition. In discussing patterns in the representation of event structure, Talmy calls them satellites in order to "capture the commonality between such particles and comparable forms in other languages” (Talmy 2000: 103). Typologically, there are two basic language groups in terms of how the conceptual structure is mapped onto syntactic structure: a) verb-framed languages, and b) satellite-framed languages (ibid 221). Broadly speaking, the basic difference lies in whether the core schema is expressed by the main verb or by the satellite. The satellite can be either a bound affix or a free word. Thus, its category includes a variety of grammatical forms: English verb particles, German separable and 
inseparable verb prefixes, Russian verb prefixes, Chinese verb complements, etc. Verbframed languages map the core schema onto the verb and the verb is called a framing verb. Satellite-framed languages map the core schema onto the satellite (ibid 222). Let us consider Talmy’s example contrasting English and Spanish:

\section{(1) a. The bottle floated out. \\ b. La botella salió flotando. \\ 'The bottle exited floating'}

In (1a), the satellite out expresses the core schema (the path), whereas the verb float expresses the co-event. In the Spanish La botella salió flotando, the verb salir 'to exit' expresses the core schema and the gerundive form flotando 'floating' expresses the coevent of manner. Apart from the motion event exemplified above, an important framing event related to English particles is temporal contouring (or aspect). According to ample linguistic evidence, temporal contouring is conceptually, and thus syntactically and lexically, analogical with motion. As stressed by Talmy (ibid 233), even though probably all languages express aspectual notions both with lexical verbs and with constituents adjoined to the verb, one or the other tends to predominate. English, for example, has a number of aspectual verbs borrowed from Romance languages (e.g. enter, continue, terminate), but it still seems to lean towards the satellite side.

\section{I.1. Prefixes as satellites}

As proposed by Tabakowska in her analysis of Polish, the "intimidating complexity" of the phenomenon of verbal prefixation results in its categories being placed in "the border area between two morphological processes, derivation and flexion” (2003: 155). When prefixes are associated with a particular lexical content, their meaning is considered relatively transparent and regular. However, when they are categorized as flexion, i.e., when they code aspect, their meaning is viewed as abstract and much less transparent. Tabakowska's attempt to give a systematic account of Polish prefixation initiates an important question of verbal prefixes being semantically related to prepositions. In order to substantiate the above-mentioned semantic motivation, the author analyses and compares the usage of the preposition za and the prefix $-z a^{1}$. Having embraced the cognitive linguistic view of semantic structure, Tabakowska 
assumes that prefixes are never semantically empty or redundant, and even though the process of grammaticalization renders them semantically bleached, they tend to reveal their old meanings. For example, za is most frequently followed by a nominal (nom) in the instrumental (INSTR) or in the accusative (ACC) case:

(2) a. (siedzieć) za drzewem

(to sit) behind tree: INST

'to sit behind the tree'

b. (iść) za drzewo

(to walk)beyond tree: ACC

'to walk beyond the tree'

(taken from Tabakowska ibid.: 159-160)

Sentence (2a) expresses a static relation and (2b) a dynamic one, which is lexicalized by the different case markers. Structures with the instrumental are used to locate a trajector (TR) behind or beyond a landmark (LM), whereas structures with the accusative are used to denote adlative motion. Both usage types have metaphorical extensions, such as:

a. (mieszkać) za granica

(live) over border: INSTR

'live abroad'

b. (wyjechać) za granice

(go) over border: ACC

'go abroad'

c. (schować coś) za murem

(hide something) behind wall: INSTR

'(hide something) behind the wall'

d. (schować się) za mur

(hide oneself) behind wall: ACC

'(hide) behind the wall'

(taken from Tabakowska ibid.: 164)

The extension in (3a) and (3b) is defined as 'passability' - the LM is conceptualized as a boundary that separates the TR from the observer. The other extension, exemplified in (3c) and (3d), has been called 'the sense of curtain'. The LM “blocks the view of an 
area so that it cannot be seen by the observer" (Weinsberg 1973: 57, as cited in Tabakowska 2003). The correlates of these two extensions are the two main extensions from the prototype of $-z a$ : the notion of passable borderline extends into an abstract boundary. This passage from non-being into being, or non-action into action, is related to the occurrence of $z a$ - with intransitive inchoative verbs:
(4) za-plonać za-kwitnąć za-śpiewać
za-burn $\quad z a$-blossom $\quad$ za-sing
'to begin burning' 'to begin blossoming' 'to begin singing'
(taken from Tabakowska ibid.: 168)

The same kind of extensions may be claimed for Croatian. For example, it is reasonable to assume that the following two examples are similar to (3d) and (4) respectively:
(5)
a. (sakriti se) za
brdo
(hide oneself) behind
hill: ACC
'(hide) behind the hill'
b. za-paliti za-blistati
za-pjevati
za-burn za-shine za-sing

'to begin burning' 'to begin shining' 'to begin singing'

Even though traditional Croatian grammars do not describe prefixes in a semantically motivated manner, there have been some recent attempts (see for example Silić and Panjković 2005) to make an initial step towards recognizing that prefixes are not "semantically empty". Let us consider the following meanings of the prefix $u$-, which appears to be related to the corresponding u 'in':

a) 'to put something into something else' (as in for example umetnuti 'put in', unijeti 'bring in', ugraditi 'fit in', etc.;

b) 'go in' and 'go into something' (as in for example $u c ́ i$ 'go in', uroniti 'dive in', uskočiti ‘jump in', uploviti 'sail in', etc.;

c) 'join' (as in for example uključiti se ‘join (in)', učlaniti se 'join', 'become a member') (based on Silić and Pranjković 2005: 149, my translation).

It is this particular tendency towards satellites in the form of prefixes that is going to be discussed later in relation to language-internal factors determining specific meaning construal exhibited by Croatian learners of English. We are going to speculate that the 
fact that Slavic languages, unlike Romance ones, often tend to express the core schema by the satellite facilitates learners' recognition of compositionality and the role of the particle in English PV constructions ${ }^{2}$. On the other hand, we are going to suggest that this recognition is less frequent with Mexican learners of English, since Spanish expresses the core schema by the main verb.

\section{I.2. The nature of verbs}

There is a specific group of verbs whose basicness makes them particularly good material for idiomatic and grammaticalized usages. They have been called basic, light, delexical, high-frequency, easy, simple, semantically vague, schematic, etc., and they have been studied by a considerable number of authors, in various contexts, and with emphasis on different aspects of their nature and behaviour (see for example Altenberg and Granger 2001, Bybee et al. 1994, Heine et al. 1991, Heine et al. 1993, Lennon 1996, Newman 1996, 1997, 1998, 2004, Norvig and Lakoff 1987, Sinclair 1991, Svartvik and Ekedhal 1995, Svorou 1993, Sweetser 1990, Viberg 1996, Wierzbicka 1988) ${ }^{3}$.

The most relevant aspect for this work is related to their role in the process of the construction of meaning in L2. Discussing high-frequency verbs, such as put and take, Lennon suggests that even though learners may have a "broad outline of word meaning”, they still have a rather unclear and imprecise lexical knowledge of polysemous items and constructs such as phrasal verbs (1996: 35). Their specific nature results in two seemingly contradictory tendencies in L2 processing and meaning construction - overuse and underuse. Overuse has been attributed to their basicness and the fact they are learnt early and widely used (see for example Hasselgren 1994), and underuse has been discussed in relation to a delexicalization process which renders them vague and superfluous when used with nouns as their object (as in for example take a step or make a fortune) (see Altenberg and Granger 2001).

In the course of this work, we are going to offer evidence that supports the characterization of these basic and schematic verbs outlined above. More specifically, we are going to show that, in the process of strategic construal and processing of English particle verbs, a semantically light verb tends to provide grounds for grammatical/topological determination by yielding under the semantic "strength" of the 
particle. On the other hand, a semantically heavier verb tends to override the contribution of the particle, which results in lexical determination.

\section{PARTICLE VERBS AND L2 RESEARCH}

The theoretical aspects of the syntactic and semantic properties of particle verbs have been discussed and described by a considerable number of authors (see for example Bolinger 1971, Brinton 1988, Cappelle 2002, Dehé 2002, Gries 1999, Lindner 1981, Lipka 1972, McIntyre 2002, Quirk et al. 1985, and many others). Their discussions clarified various facets of particle verb constructions and established a solid theoretical grounding for further investigation into applied particle verb matters, especially into the complexity of their use in L2. Even though (at least to the author's knowledge) there are no studies which are tightly related to the topic of this paper, there is a body of applied research concerned with the avoidance of particle verbs that is directly relevant for some of our hypotheses.

Dagut and Laufer (1985) were the first to tackle the issue of avoidance of particle verbs in a study in which they investigated Hebrew-speaking learners of English. The authors attributed the process of avoidance to the fact that Hebrew does not have particle verbs. It is also important to add that the use of particle verbs depended on their semantic nature, i.e., opaque, idiomatic verbs were used least often, literal particle verbs most frequently, and the use of aspectual (completive) verbs comes somewhere between the two. However, the semantic nature of the verbs was not considered as a factor affecting their avoidance.

Following Dagut and Laufer's conclusions, Hulstijn and Marchena (1989) hypothesized that learners with a Germanic L1 would not avoid particle verbs. Furthermore, they assumed that non-avoidance would correlate with learners' language proficiency. The results showed that: a) Dutch intermediate learners used fewer particle verbs than advanced students, and b) both intermediate and advanced learners used more particle verbs than the Hebrew learners from Hulstijn and Marchena's study ${ }^{4}$. Furthermore, the participants in the study used idiomatic particle verbs less frequently than those verbs whose meaning is less specialized and more literal. Finally, both intermediate and advanced learners avoided both idiomatic and aspectual verbs that were similar to their 
Dutch equivalents, which indicated that similarities between L1 and L2 may function as constraints rather than facilitators.

Unlike previous researchers, Liao and Fukuya (2004) also concentrated on the semantics of the verbs, and their results showed the following: a) Chinese intermediate learners of English used fewer particle verbs than advanced learners, b) advanced learners used nearly as many phrasal verbs as native speakers, c) both groups of learners used literal phrasal verbs more frequently than idiomatic ones, and d) intermediate learners used even fewer idiomatic verbs than advanced learners.

The most recent study on particle verb avoidance is Waibel (2007). The empirical strength of this study lies in the fact that the author used learner corpora. The results showed that, contrary to expectations, particle verbs are not "universally underused" (ibid 77). The data showed that learners with a Germanic L1 performed like native students. Finnish learners and those with a Slavic L1 used around 300 phrasal-verb tokens less than native students, and learners with a Romance L1 used only about half as many phrasal verbs as native students.

While discussing reasons for differences in performance in the three groups, the author stresses typological similarities and differences between English and other Germanic languages, and between English and Romance and Slavic languages. The fact that the extent of underuse is more prominent in the writing of students with a Romance L1 is explained by the lack of particle verbs or any similar verb types in French, Italian and Spanish. However, even though the author stresses that the same is the case with Slavic languages, and adds that verb aspect and aktionsart are marked by pre- or suffixation, she seems to neglect the fact that Slavic and Germanic languages typologically belong to the same group of languages in terms of how they map the core schema (see section I.1.). More specifically, it is reasonable to assume that the existence of a satellite, be it a bound affix or a free word, plays a very important role in meaning construal and use of particle-verb constructions. As suggested in section I.1., aspectual meaning is just one of many semantic contributions made by prefixes as verb satellites. Thus, the fact that Slavic learners underuse particle verbs less than learners from a Romance background is not that surprising. 
The results obtained using German and Italian sub-corpora support the above-mentioned results, i.e., when compared to native students, German learners used more and Italian learners fewer particle verbs in relation to the overall number of verbs (ibid.: 84). Furthermore, German students used more Germanic-based verbs, whereas Italian students used more Romance-based verbs ${ }^{5}$.

In this section, we have selected and outlined several findings related to studies focusing on the avoidance of particle verbs. In the section that follows, we give a brief description of the scope of the present study in relation to the above-mentioned findings and the overall research procedure.

\section{THE SCOPE OF THE PRESENT STUDY}

What we sought to establish was if/how the users of English make sense of PVs and how much they rely on topological components in the process of constructing meaning. Given the nature of verbs that form PVs (light vs. heavy) and the nature of our participants' L1 (Spanish being a prototypical verb-framed language vs. Croatian containing both verb-only and verb-plus-satellite structures), the following hypotheses were formulated:

1) Topological determination is expected with PVs containing light lexical parts.

2) Lexical determination is expected with PVs containing heavy lexical parts.

3) A more "balanced" determination (= compositionality) is expected with PVs containing heavy lexical parts.

4) Topological determination and higher frequency of compositional meanings are expected in Croatian users of English.

5) Lexical determination and lower frequency of compositional meanings are expected in Mexican users of English.

\section{III.1. The instrument}

The instrument used was a questionnaire that consisted of 20 particle verbs. The criteria used to choose these particular examples were as follows: a) particle verb constructions with both heavy and light lexical parts, b) similar number of meanings in the two 
groups, and c) all meanings validated as metaphoric/obscure. Three light and seven heavy verbs were selected: go, take, put and call, cut, break, draw, pull, shut, write. All verbs had to be semantically productive with both in and out. After the particle verbs had been selected, we designed a questionnaire using all the meanings listed in three phrasal verb dictionaries. In order to obtain metaphoric meanings we used a simple triangulation test - the meanings were judged by two linguists, 5 native speakers and 40 English majors (final year of study). They were all asked to place each meaning on a scale from 1 to 5, 1 being "the most literal" and 5 being "the most abstract/metaphoric" meaning. The result was the 45 meanings used in the research.

\section{III.2. The sample and the procedure}

The sample consisted of 100 users of English - proficient English majors from Croatia and Mexico: 68 students from the Faculty of Philosophy, University of Zagreb (Filozofski fakultet, Sveučilište u Zagrebu), and 32 students from the Faculty of Philosophy at UNAM (Facultad de Filosofía y Letras, Universidad Nacional Autónoma de México, Mexico City). They were tested separately at their respective universities. Our primary aim was to have two groups of experienced learners of English with similar educational backgrounds and language proficiency but a different first language. What we had not expected was to find that there were almost three times fewer English majors at UNAM than at the University of Zagreb. Furthermore, the year of study in Mexico, as opposed to Croatia, does not guarantee a particular level of language proficiency. Thus, it was decided that in Croatia we would work with the 3rd and 4th year students, whereas in Mexico participants would be a group of students attending the last level of their academic language courses.

The first step in the final stage of the research was to test their language proficiency. After the proficiency test, the participants were scheduled to attend two separate sessions to complete the research questionnaire. In order to conduct both quantitative and qualitative analyses, all the answers were first copied, grouped and sequenced alphabetically. 


\section{III.3. The data}

After the data (2207 answers for out and 1991 for in) had been copied, grouped and sequenced, each answer was coded ${ }^{\underline{6}}$ with one of the following codes:

1) TOP for topological determination (the answers in which the meaning of the particle overrides the meaning of the lexical part of the construction);

2) $\mathbf{L X}$ for lexical determination (the answers in which the meaning of the lexical part overrides the meaning of the particle);

3) CMP for compositional meaning;

4) PPH for paraphrase;

5) OPP for basic opposition (e.g. go in explained in terms of being opposite to go out, or in being explained in terms of being opposite to out);

6) MIS for misinterpretation (examples where the answer is in no way related to the PV construction);

7) CTX for examples where situational context is provided without the PV itself being used or explained;

8) LXD for examples with PV constructions being lexicalized, that is, a Latinate verb offered as an explanation.

Let us briefly illustrate the three categories that are crucial for this paper. The particle verb and its meaning are followed by a few examples of the participants' answers.

a) Topological determination:

- break out ('become covered in something, like in sweat or rash') - "something goes out of you and you cannot control it, it is out and you cannot put it back in by will”;

- put in ('elect a political party as the government') - "the government is a place in which you put the elected political party to do something”.

b) Lexical determination:

- draw out ('make something last longer') - "draw indicates that the action is prolonged, it means to stretch, to extend";

- call in ('make a short visit usually on the way to another place') - "when you want to visit somebody you usually call them to see if they are home’).

c) Compositional meaning: 
- break out ('become covered in something like in sweat or rash') - “out something gets out in the open, it is visible to everybody, break - a sudden, unexpected act”;

- call in ('make a short visit usually on the way to another place') - "call because it is a short visit just like a phone call, and in is the place that you visit”.

The final step towards obtaining an initial set of quantitative results was to feed all the information into a statistical program. The program used was SPSS and the information processed consisted of the following data: the participants' research number, year of study, years of learning English, score on the proficiency test, all the answers, and all the accompanying codes.

\section{RESULTS}

\section{IV.1. Type of determination: light vs. heavy}

There were three hypotheses related to the type of determination:

1) Topological determination ${ }^{7}$ is expected with PVs containing light lexical parts.

2) Lexical determination is expected with PVs containing heavy lexical parts.

3) A more "balanced" determination (=compositionality) ${ }^{\underline{8}}$ is expected with PVs containing heavy lexical parts.

\section{IV.1.1. Results for out}

For particle verb constructions with out, the analysis of the data revealed that there is a statistically significant difference between aspects of strategic construal with PVs containing light lexical parts and PVs containing heavy lexical parts. More specifically:

a) there is more topological determination with PVs with light lexical parts $(M=29.47)$ than with PVs with heavy lexical parts $(M=10.48)$ (see Tables 1 and 2). The numbers show that $29.47 \%$ of participants explained the meaning of particle verb constructions with light verbs in such a way as to refer to topology, whereas only $10.48 \%$ of participants did the same while describing particle verb 
constructions with heavy verbs. The difference proved to be statistically significant ( $\mathrm{t}=7.073 ; \mathrm{p}<.01)$ (see Table 3$)$.

Table 1. Average occurrence of particular answers (codes) for light verbs in the whole sample.

\begin{tabular}{|l|l|r|r|r|r|r|r|r|r|}
\hline & \multicolumn{2}{|c|}{$\begin{array}{l}\text { ALIG } \\
\text { TOP }\end{array}$} & $\begin{array}{l}\text { ALIG } \\
L X\end{array}$ & $\begin{array}{l}\text { ALIG } \\
\text { CMP }\end{array}$ & $\begin{array}{l}\text { ALIG_- } \\
\text { PPH }\end{array}$ & $\begin{array}{l}\text { ALIG } \\
\text { OPP }\end{array}$ & $\begin{array}{l}\text { ALIG } \\
\text { MIS }\end{array}$ & $\begin{array}{l}\text { ALIG } \\
\text { CTX }\end{array}$ & $\begin{array}{l}\text { ALIG } \\
\text { LXD }\end{array}$ \\
\hline$N$ & Valid & 62 & 62 & 62 & 62 & 62 & 62 & 62 & 62 \\
\hline & Missing & 38 & 38 & 38 & 38 & 38 & 38 & 38 & 38 \\
\hline $\begin{array}{l}\text { Mean } \\
\%\end{array}$ & & .2947 & .0147 & .2023 & .2522 & .0469 & .1950 & .0411 & .0293 \\
\hline
\end{tabular}

Table 2. Average occurrence of particular answers (codes) for heavy verbs in the whole sample.

\begin{tabular}{|l|l|r|r|r|r|r|r|r|r|}
\hline & & $\begin{array}{l}\text { AHEA } \\
\text { TOP }\end{array}$ & $\begin{array}{l}\text { AHEA } \\
L X\end{array}$ & $\begin{array}{l}\text { AHEA } \\
\text { CMP }\end{array}$ & $\begin{array}{l}\text { AHEA } \\
\text { PPH }\end{array}$ & $\begin{array}{l}\text { AHEA } \\
\text { OPP }\end{array}$ & $\begin{array}{l}\text { AHEA } \\
\text { MIS }\end{array}$ & $\begin{array}{l}\text { AHEA_ } \\
\text { CTX }\end{array}$ & $\begin{array}{l}\text { AHEA } \\
\text { LXD }\end{array}$ \\
\hline$N$ & Valid & 70 & 70 & 69 & 70 & 70 & 69 & 70 & 70 \\
\hline & Missing & 30 & 30 & 31 & 30 & 30 & 31 & 30 & 30 \\
\hline Mean & & .1048 & .1429 & .2947 & .2821 & .0512 & .1280 & .0381 & .0381 \\
\hline $\begin{array}{l}\text { Mean } \\
\%\end{array}$ & & 10.48 & 14.29 & 29.47 & 28.21 & 5.12 & 12.80 & 3.81 & 3.81 \\
\hline
\end{tabular}

Table 3. Paired samples comparison of average occurrence of particular answers (codes) for light and heavy verbs in the whole sample.

\begin{tabular}{|c|c|c|c|c|c|c|}
\hline & & Mean & $N$ & Std. Deviation & t-test & $p$ \\
\hline Pair 1 & ALIG_TOP & .2933 & 53 & .22526 & \multirow{2}{*}{7.073} & \multirow{2}{*}{$<.01$} \\
\hline & AHEA_TOP & .1053 & 53 & .11341 & & \\
\hline Pair 2 & ALIG_LX & .0086 & 53 & .03221 & \multirow{2}{*}{-7.400} & \multirow{2}{*}{$<.01$} \\
\hline & AHEA_LX & .1557 & 53 & .13967 & & \\
\hline Pair 3 & ALIG_CMP & .2230 & 53 & .28613 & \multirow{2}{*}{-3.743} & \multirow{2}{*}{$<.01$} \\
\hline & AHEA_CMP & .3286 & 53 & .29527 & & \\
\hline Pair 4 & ALIG_PPH & .2607 & 53 & .19452 & \multirow{2}{*}{.440} & \multirow{2}{*}{$>.01$} \\
\hline & AHEA_PPH & .2516 & 53 & .19982 & & \\
\hline Pair 5 & ALIG_OPP & .0497 & 53 & .06567 & \multirow{2}{*}{.489} & \multirow{2}{*}{$>.01$} \\
\hline & AHEA_OPP & .0550 & 53 & .07113 & & \\
\hline Pair 6 & ALIG_MIS & .1836 & 52 & .12918 & \multirow{2}{*}{2.754} & \multirow{2}{*}{$<.01$} \\
\hline & AHEA_MIS & .1266 & 52 & .14338 & & \\
\hline Pair 7 & ALIG_CTX & .0326 & 53 & .09280 & \multirow{2}{*}{.258} & \multirow{2}{*}{$>.01$} \\
\hline & AHEA_CTX & .0299 & 53 & .08662 & & \\
\hline Pair 8 & ALIG_LXD & .0292 & 53 & .04640 & \multirow{2}{*}{.280} & \multirow{2}{*}{$>.01$} \\
\hline & AHEA_LXD & .0267 & 53 & .05364 & & \\
\hline
\end{tabular}

b) Conversely, as many as $14.29 \%$ of the participants (see Table 2 ) implied lexical determination while describing PVs with heavy lexical parts, whereas only $1.47 \%$ of the participants did so while describing PVs with light lexical parts (see Table 1$)$. The difference is statistically significant $(\mathrm{t}=-7.400 ; \mathrm{p}<.01)$.

c) Furthermore, $29.47 \%$ of the participants described the PV constructions with heavy lexical parts by implying compositionality of meaning, whereas only 
20.23\% of the participants (see Tables 1 and 2) did so while explaining the meaning of PV constructions with light verbs. The difference in usage is significant $(\mathrm{t}=-3.743 ; \mathrm{p}<.01)$ (see Table 3$)$.

The results show that the semantic weight of both verbs and particles plays a significant role in the process of meaning construction in L2. On the one hand, semantically light verbs are delexicalized and schematic and, thus, they are likely to be construed as vague and superfluous. On the other hand, particles such as in and out are omnipresent and highly productive, they are the most immediate conceptual tool for mental structuring of space, they build paths and temporal contouring of events, they code change in state of existence, and so forth. Hence, learners' reliance on particles is not surprising. It is also important to mention that the results support previous findings associated with the underuse of high-frequency verbs in L2 processing.

Furthermore, the nature of the contribution of light and heavy verbs is also evident in the results related to compositionality. It seems easier for learners to find a semantic relation between a heavy verb and the meaning assigned to the whole construction than between a semantically vague verb and its construction. In more general terms, this is another piece of evidence showing that meanings are subjective and dynamic. Even though we may claim that the tendency described above is a predictable pattern, the overall semantic picture for L2 is the following: compositionality is partial and gradient. What this means is that: a) the relation between a PV composite structure and its components is not arbitrary, b) a composite structure is not constructed out of its components, nor is it fully predictable, and c) the continuum of compositionality is likely to have various stages, with each stage corresponding to a particular aspect of strategic construal.

In other words, the only cognitively realistic description of the construal of the meaning of PVs in L2 is the one that accounts for all the data obtained. What the data show is that the extent to which learners are cognizant of the semantic contribution of component elements, i.e., the analysability of PV constructions, varies considerably in the whole sample. Discrepancies between the expected compositional meaning and the actual meaning lessen the degree of analysability, which results in a variety of strategic construals with salience being shifted from one aspect to another. Thus, in the same 
manner that is claimed for native speakers, learners use the components as some sort of "scaffolding" that helps one "reach" the composite structure (Langacker 2000: 152, original emphasis). Sometimes it seems easier to reach a particular PV via its verb, on some other occasions via its satellite, and sometimes both components seem to correspond to certain aspects of the composite structure. The only logical conclusion is that the semantic continuum of strategic construal of PVs runs from learners relying exclusively on semantically heavy verbs to finding primary motivation for meaning in highly grammaticalized particles. In between the two extremes relating to either lexical or topological/grammatical determination, there are a number of intermediate cases involving gradient and partial compositionality (see Figure 1).

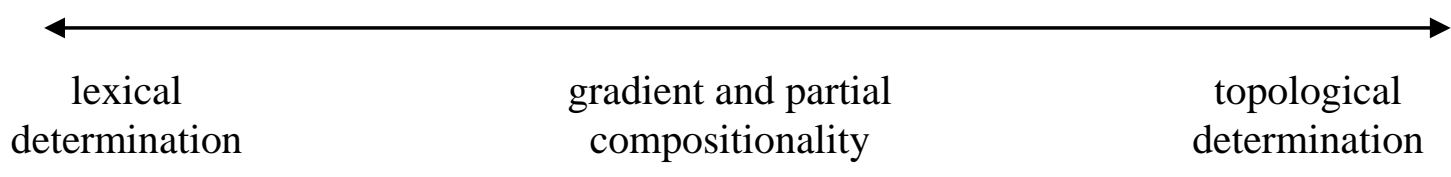

Figure 1. Semantic determination in the strategic construal of particle verbs.

\section{IV.1.2. Results for in}

For particle verb constructions with in, the analysis of the data revealed the following:

a) There is more topological determination with PVs with light lexical parts $(M=29.78)$ than with PVs with heavy lexical parts $(M=7.06)$ (see Tables 4 and 5). Only $7.06 \%$ of the participants referred to topology while explaining the PV constructions with semantically heavy lexical parts, whereas as many as $29.78 \%$ of the participants referred to the topological part of the construction while explaining the meaning of PVs with light lexical parts. The difference is statistically significant $(\mathrm{t}=7.785 ; \mathrm{p}<.01)$ (see Table 6).

b) Conversely, there is more lexical determination with PVs with heavy lexical parts $(M=17.66)$ than with PVs with light lexical parts $(M=1.54)$ (see Tables 4 and 5). In the process of constructing the meaning of PVs with heavy lexical parts, as many as $17.66 \%$ of the participants relied on the meaning of the lexical part of the construction, and only $1.54 \%$ of the participants did so while constructing the meaning of PVs with light lexical parts. The difference is statistically significant $(\mathrm{t}=7.266 ; \mathrm{p}<.01)($ see Table 6$)$. 
c) Finally, there is a higher frequency of compositional meanings with PVs containing heavy lexical parts $(\mathrm{M}=36.86)$ than with PVs containing light lexical parts $(M=22.69)$. The numbers show that $36.86 \%$ of the participants attended equally to both parts of the construction while constructing the meaning of the particle verbs containing heavy verbs, whereas they attended significantly less to both parts of the construction in the process of constructing and explaining the meaning of the particle verbs with light verbs $(\mathrm{t}=-4.507 ; \mathrm{p}<.01)$ (see Table 6$)$.

Table 4. Average occurrence of particular answers (codes) for light verbs in the whole sample.

\begin{tabular}{|l|l|r|r|r|r|r|r|r|r|}
\hline & & $\begin{array}{l}A L I G_{-} \\
T O P\end{array}$ & $\begin{array}{l}A L I G_{-} \\
L X\end{array}$ & $\begin{array}{l}A L I G_{-} \\
C M P\end{array}$ & $\begin{array}{l}A L I G_{-} \\
P P H\end{array}$ & $\begin{array}{l}A L I G_{-} \\
\text {OPP }\end{array}$ & $\begin{array}{l}\text { ALIG } \\
\text { MIS }\end{array}$ & $\begin{array}{l}\text { ALIG } \\
\text { CTX }\end{array}$ & $\begin{array}{l}\text { ALIG } \\
\text { LXD }\end{array}$ \\
\hline$N$ & Valid & 72 & 72 & 72 & 72 & 72 & 72 & 72 & 72 \\
\hline & Missing & 28 & 28 & 28 & 28 & 28 & 28 & 28 & 28 \\
\hline Mean & & .2978 & .0154 & .2269 & .2469 & .0077 & .1543 & .0448 & .0139 \\
\hline $\begin{array}{l}\text { Mean } \\
\%\end{array}$ & & 29.78 & 1.54 & 22.69 & 24.69 & .77 & 15.43 & 4.48 & 1.39 \\
\hline
\end{tabular}

Table 5. Average occurrence of particular answers (codes) for heavy verbs in the whole sample.

\begin{tabular}{|l|l|r|r|r|r|r|r|r|r|}
\hline & & $\begin{array}{l}\text { AHEA } \\
\text { TOP }\end{array}$ & $\begin{array}{l}\text { AHEA } \\
\text { LX }\end{array}$ & $\begin{array}{l}\text { AHEA } \\
\text { CMP }\end{array}$ & $\begin{array}{l}\text { AHEA } \\
\text { PPH }\end{array}$ & $\begin{array}{l}\text { AHEA- } \\
\text { OPP }\end{array}$ & $\begin{array}{l}\text { AHEA_ } \\
\text { MIS }\end{array}$ & $\begin{array}{l}\text { AHEA_ } \\
\text { CTX }\end{array}$ & $\begin{array}{l}\text { AHEA } \\
\text { LXD }\end{array}$ \\
\hline$N$ & Valid & 59 & 59 & 59 & 58 & 58 & 59 & 59 & 59 \\
\hline & Missing & 41 & 41 & 41 & 42 & 42 & 41 & 41 & 41 \\
\hline Mean & & .0706 & .1766 & .3686 & .1983 & .0101 & .1441 & .0410 & .0042 \\
\hline $\begin{array}{l}\text { Mean } \\
\%\end{array}$ & & 7.06 & 17.66 & 36.86 & 19.83 & 1.01 & 14.41 & 4.01 & .42 \\
\hline
\end{tabular}

Table 6. Paired samples comparison of the average occurrence of particular answers (codes) for light and heavy verbs in the whole sample.

\begin{tabular}{|c|c|c|c|c|c|c|}
\hline & & Mean & $N$ & Std. Deviation & t-test & $p$ \\
\hline Pair 1 & ALIG_TOP & .3072 & 51 & .21953 & \multirow{2}{*}{7.785} & \multirow{2}{*}{$<.01$} \\
\hline & AHEA_TOP & .0784 & 51 & .09634 & & \\
\hline Pair 2 & ALIG_LX & .0153 & 51 & .04979 & \multirow{2}{*}{-7.266} & \multirow{2}{*}{$<.01$} \\
\hline & AHEA_LX & .1797 & 51 & .16863 & & \\
\hline Pair 3 & ALIG_CMP & .2462 & 51 & .25074 & \multirow{2}{*}{-4.507} & \multirow{2}{*}{$<.01$} \\
\hline & AHEA_CMP & .3840 & 51 & .24893 & & \\
\hline Pair 4 & ALIG_PPH & .2533 & 50 & 64 & \multirow{2}{*}{2.477} & \multirow{2}{*}{$>.01$} \\
\hline & AHEA_PPH & .1817 & 50 & .19099 & & \\
\hline Pair 5 & ALIG_OPP & .0065 & 51 & .02640 & \multirow{2}{*}{-.852} & \multirow{2}{*}{$>.01$} \\
\hline & HEA_OPP & .0114 & 51 & .02896 & & \\
\hline Pair 6 & ALIG_MIS & .1481 & 51 & .16875 & \multirow{2}{*}{.046} & \multirow{2}{*}{$>.01$} \\
\hline & AHEA_MIS & .1471 & 51 & 62 & & \\
\hline Pair 7 & ALIG_CTX & .0305 & 51 & .07723 & \multirow{2}{*}{124} & \multirow{2}{*}{$>.01$} \\
\hline & AHEA_CTX & .0294 & 51 & .08948 & & \\
\hline Pair 8 & ALIG_LXD & .0022 & 51 & .01556 & \multirow{2}{*}{-.340} & \multirow{2}{*}{$>.01$} \\
\hline & AHEA_LXD & .0033 & 51 & .01634 & & \\
\hline
\end{tabular}


The results show that the semantic determination for PVs with in is consistent with the one found for out. Furthermore, the participants used the same avoidance strategies. The only difference found is that there is no significant difference in the frequency of misinterpretations in relation to PVs with light or heavy verbs, i.e., all strategies are equally frequent with both kinds of constructions (see Table 6). This may be attributed to the fact that in was generally found to be much less informative for learners than out (see the second part of the chapter dealing with the strategic construal of particles), and in combination with heavy verbs it often produces very specialized meanings that are difficult to predict.

\section{IV.2. Type of determination and L1}

\section{IV.2.1. PVs with out: semantic determination and L1}

Given the typological differences between Spanish and Croatian, as well as the abovediscussed differences in the nature of the verbs forming the PVs selected for this research, our hypotheses were:

a) topological determination and higher frequency of compositional meanings are expected in the Croatian learners of English;

b) lexical determination and lower frequency of compositional meanings are expected in the Mexican learners of English.

Several observable differences between Mexicans and Croats were found:

a) with light verbs with out, compositionality is significantly more frequent in the group of Croats. Tables 7 (Croats) and 8 (Mexicans) show average frequencies of the three types of determination and other strategies in the process of meaning construal. Table 9 shows statistically significant differences between the two groups:

Table 7. Average occurrence of particular answers (codes) for light verbs in the group of Croats.

\begin{tabular}{|l|l|r|r|r|r|r|r|r|r|}
\hline & & $\begin{array}{l}A L I G_{-} \\
T O P\end{array}$ & $\begin{array}{l}A L I G_{-} \\
L X\end{array}$ & $\begin{array}{l}A L I G_{-} \\
C M P\end{array}$ & $\begin{array}{l}A L I G_{-} \\
P P H\end{array}$ & $\begin{array}{l}A L I G_{-} \\
\text {OPP }\end{array}$ & $\begin{array}{l}A L I G_{-} \\
\text {MIS }\end{array}$ & $\begin{array}{l}A L I G_{-} \\
C T X\end{array}$ & $\begin{array}{l}A L I G_{-} \\
\text {LXD }\end{array}$ \\
\hline$N$ & Valid & 36 & 36 & 36 & 36 & 36 & 36 & 36 & 36 \\
\hline & Missing & 32 & 32 & 32 & 32 & 32 & 32 & 32 & 32 \\
\hline Mean & & .3384 & .0051 & .2702 & .2273 & .0505 & .1692 & .0076 & .0328 \\
\hline Mean \% & & 33.84 & 0.51 & 27.02 & 22.73 & 5.05 & 16.92 & .76 & 3.28 \\
\hline
\end{tabular}


Table 8. Average occurrence of particular answers (codes) for light verbs in the group of Mexicans.

\begin{tabular}{|l|l|r|l|r|r|r|r|r|r|}
\hline & & $\begin{array}{l}A L I G_{-} \\
\text {TOP }\end{array}$ & $\begin{array}{l}\text { ALIG } \\
L X\end{array}$ & $\begin{array}{l}\text { ALIG } \\
\text { CMP }\end{array}$ & $\begin{array}{l}\text { ALIG } \\
\text { PPH }\end{array}$ & $\begin{array}{l}\text { ALIG } \\
\text { OPP }\end{array}$ & $\begin{array}{l}\text { ALIG } \\
\text { MIS }\end{array}$ & $\begin{array}{l}\text { ALIG } \\
\text { CTX }\end{array}$ & $\begin{array}{l}\text { ALIG } \\
\text { LXD }\end{array}$ \\
\hline$N$ & Valid & 26 & 26 & 26 & 26 & 26 & 26 & 26 & 26 \\
\hline & Missing & 6 & 6 & 6 & 6 & 6 & 6 & 6 & 6 \\
\hline Mean & & .2343 & .0280 & .1084 & .2867 & .0420 & .2308 & .0874 & .0245 \\
\hline Mean \% & & 23.43 & 2.80 & 10.84 & 28.67 & 4.20 & 23.08 & 8.74 & 2.45 \\
\hline
\end{tabular}

Table 9. Descriptive statistics and mean differences for average occurrence of particular answers (codes) for light verbs (Mexicans vs. Croats).

\begin{tabular}{|c|c|c|c|c|c|c|}
\hline & & $N$ & Mean & Std. Deviation & $t$-test & $p$ \\
\hline ALIG_TOP & Croats & 36 & .3384 & .22013 & \multirow{2}{*}{1.876} & \multirow{2}{*}{$>.01$} \\
\hline & Mexicans & 26 & .2343 & .20917 & & \\
\hline$A L I G \_L X$ & Croats & 36 & .0051 & .02112 & \multirow{2}{*}{-2.203} & \multirow{2}{*}{$>.01$} \\
\hline & Mexicans & 26 & .0280 & .04992 & & \\
\hline ALIG_CMP & Croats & 36 & .2702 & .32560 & \multirow{2}{*}{2.714} & \multirow{2}{*}{$<.01$} \\
\hline & Mexicans & 26 & .1084 & .12602 & & \\
\hline$A L I G \_P P H$ & Croats & 36 & .2273 & .19007 & \multirow{2}{*}{-1.259} & \multirow{2}{*}{$>.01$} \\
\hline & Mexicans & 26 & .2867 & .17381 & & \\
\hline ALIG_OPP & Croats & 36 & .0505 & .06678 & \multirow{2}{*}{.522} & \multirow{2}{*}{$>.01$} \\
\hline & Mexicans & 26 & .0420 & .05881 & & \\
\hline$A L I G \_M I S$ & Croats & 36 & .1692 & .12129 & \multirow{2}{*}{-1.825} & \multirow{2}{*}{$>.01$} \\
\hline & Mexicans & 26 & .2308 & .14370 & & \\
\hline ALIG_CTX & Croats & 36 & .0076 & .02548 & \multirow{2}{*}{-2.562} & \multirow{2}{*}{$>.01$} \\
\hline & Mexicans & 26 & .0874 & .15742 & & \\
\hline ALIG_LXD & Croats & 36 & .0328 & .04933 & \multirow{2}{*}{.704} & \multirow{2}{*}{$>.01$} \\
\hline & Mexicans & 26 & .0245 & .04112 & & \\
\hline
\end{tabular}

b) with heavy verbs with out, compositionality is significantly more frequent in the group of Croats and lexical determination is significantly less frequent in the group of Croats than in the group of Mexicans. Tables 10 and 11 show average frequency of determination and Table 12 shows statistically significant differences.

Table 10. Average occurrence of particular answers (codes) for heavy verbs in the group of Croats.

\begin{tabular}{|l|r|r|r|r|r|r|r|r|r|}
\hline & & $\begin{array}{l}\text { AHEA } \\
\text { TOP }\end{array}$ & $\begin{array}{l}\text { AHEA } \\
L X\end{array}$ & $\begin{array}{l}\text { AHEA } \\
\text { CMP }\end{array}$ & $\begin{array}{l}\text { AHEA } \\
\text { PPH }\end{array}$ & $\begin{array}{l}\text { AHEA } \\
\text { OPP }\end{array}$ & $\begin{array}{l}\text { AHEA } \\
\text { MIS }\end{array}$ & $\begin{array}{l}\text { AHEA } \\
\text { CTX }\end{array}$ & $\begin{array}{l}\text { AHEA } \\
\text { LXD }\end{array}$ \\
\hline$N$ & \multicolumn{1}{|c|}{ Valid } & 46 & 46 & 46 & 46 & 46 & 45 & 46 & 46 \\
\hline & Missing & 22 & 22 & 22 & 22 & 22 & 23 & 22 & 22 \\
\hline Mean & & .1105 & .1069 & .3605 & .2663 & .0507 & .0981 & .0326 & .0562 \\
\hline Mean \% & & 11.05 & 10.69 & 36.05 & 26.63 & 5.07 & 9.81 & 3.26 & 5.62 \\
\hline
\end{tabular}


Table 11. Average occurrence of particular answers (codes) for heavy verbs in the group of Mexicans.

\begin{tabular}{|l|l|r|l|r|r|r|r|r|r|}
\hline & & $\begin{array}{l}\text { AHEA_ } \\
\text { TOP }\end{array}$ & $\begin{array}{l}\text { AHEA } \\
\text { LX }\end{array}$ & $\begin{array}{l}\text { AHEA } \\
\text { CMP }\end{array}$ & $\begin{array}{l}\text { AHEA_ } \\
\text { PPH }\end{array}$ & $\begin{array}{l}\text { AHEA_ } \\
\text { OPP }\end{array}$ & $\begin{array}{l}\text { AHEA_ } \\
\text { MIS }\end{array}$ & $\begin{array}{l}\text { AHEA- } \\
\text { CTX }\end{array}$ & $\begin{array}{l}\text { AHEA } \\
\text { LXD }\end{array}$ \\
\hline$N$ & Valid & 24 & 24 & 23 & 24 & 24 & 24 & 24 & 24 \\
\hline & Missing & 8 & 8 & 9 & 8 & 8 & 8 & 8 & 8 \\
\hline Mean & & 0.0938 & .2118 & .1630 & .3125 & .0521 & .1840 & .0486 & .0035 \\
\hline Mean \% & & 9.38 & 21.18 & 16.30 & 31.25 & 5.21 & 18.40 & 4.86 & .35 \\
\hline
\end{tabular}

Table 12. Descriptive statistics and mean differences for average occurrence of particular answers (codes) for heavy verbs (Mexicans vs. Croats)

\begin{tabular}{|c|c|c|c|c|c|c|}
\hline & $H R \_M E X$ & $N$ & Mean & Std. Deviation & t-test & $p$ \\
\hline AHEA_TOP & Croats & 46 & .1105 & .12675 & \multirow{2}{*}{.563} & \multirow{2}{*}{$>.01$} \\
\hline & Mexicans & 24 & .0937 & .09925 & & \\
\hline AHEA_LX & Croats & 46 & .1069 & .12989 & \multirow{2}{*}{-3.267} & \multirow{2}{*}{$<.01$} \\
\hline & Mexicans & 24 & .2118 & .12282 & & \\
\hline AHEA_CMP & Croats & 46 & .3605 & 381 & \multirow{2}{*}{2.805} & \multirow{2}{*}{$<.01$} \\
\hline & Mexicans & 23 & .1630 & .20640 & & \\
\hline AHEA_PPH & Croats & 46 & .2663 & .22813 & \multirow{2}{*}{-.864} & \multirow{2}{*}{$>.01$} \\
\hline & Mexicans & 24 & .3125 & .17763 & & \\
\hline AHEA_OPP & Croats & 46 & .0507 & .07345 & \multirow{2}{*}{-.075} & \multirow{2}{*}{$>.01$} \\
\hline & Mexicans & 24 & .0521 & .06869 & & \\
\hline AHEA_MIS & Croats & 45 & .0981 & .13211 & \multirow{2}{*}{-2.512} & \multirow{2}{*}{$>.01$} \\
\hline & Mexicans & 24 & .1840 & 112 & & \\
\hline AHEA_CTX & Croats & 46 & .0326 & .10165 & \multirow{2}{*}{-.597} & \multirow{2}{*}{$>.01$} \\
\hline & Mexicans & 24 & .0486 & .11504 & & \\
\hline AHEA_LXD & Croats & 46 & .0562 & .07039 & \multirow{2}{*}{4.814} & \multirow{2}{*}{$<.01$} \\
\hline & Mexicans & 24 & .0035 & .01701 & & \\
\hline
\end{tabular}

\section{IV.2.2. PVs with in: semantic determination and L1}

a) With light verbs with in, no significant differences were found between the two groups of learners (see Tables 13 and 14 for average frequency of types of determination and Table 15 for significant differences).

Table 13. Average occurrence of particular answers (codes) for light verbs in the group of Croats.

\begin{tabular}{|l|l|r|r|r|r|r|r|r|r|}
\hline & & $\begin{array}{l}A L I G_{-} \\
\text {TOP }\end{array}$ & $\begin{array}{l}\text { ALIG } \\
L X\end{array}$ & $\begin{array}{l}\text { ALIG } \\
\text { CMP }\end{array}$ & $\begin{array}{l}\text { ALIG } \\
\text { PPH }\end{array}$ & $\begin{array}{l}\text { ALIG } \\
\text { OPP }\end{array}$ & $\begin{array}{l}\text { ALIG } \\
\text { MIS }\end{array}$ & $\begin{array}{l}\text { ALIG } \\
\text { CTX }\end{array}$ & $\begin{array}{l}\text { ALIG } \\
\text { LXD }\end{array}$ \\
\hline$N$ & Valid & 47 & 47 & 47 & 47 & 47 & 47 & 47 & 47 \\
\hline & Missing & 21 & 21 & 21 & 21 & 21 & 21 & 21 & 21 \\
\hline Mean & & .3002 & .0142 & .2175 & .2648 & .0095 & .1631 & .0378 & .0024 \\
\hline Mean \% & & 30.02 & 1.42 & 21.75 & 26.48 & .95 & 16.31 & 3.78 & .24 \\
\hline
\end{tabular}


Table 14. Average occurrence of particular answers (codes) for light verbs in the group of Mexicans.

\begin{tabular}{|l|l|r|l|r|r|r|r|r|r|}
\hline & & $\begin{array}{l}\text { ALIG } \\
\text { TOP }\end{array}$ & $\begin{array}{l}\text { ALIG } \\
L X\end{array}$ & $\begin{array}{l}\text { ALIG } \\
\text { CMP }\end{array}$ & $\begin{array}{l}\text { ALIG } \\
\text { PPH }\end{array}$ & $\begin{array}{l}\text { ALIG } \\
\text { OPP }\end{array}$ & $\begin{array}{l}\text { ALIG } \\
\text { MIS }\end{array}$ & $\begin{array}{l}\text { ALIG } \\
\text { CTX }\end{array}$ & $\begin{array}{l}\text { ALIG } \\
\text { LXD }\end{array}$ \\
\hline$N$ & Valid & 25 & 25 & 25 & 25 & 25 & 25 & 25 & 25 \\
\hline & Missing & 7 & 7 & 7 & 7 & 7 & 7 & 7 & 7 \\
\hline Mean & & .2933 & .0178 & .2444 & .2133 & .0044 & .1378 & .0578 & .0356 \\
\hline Mean \% & & 29.33 & 1.78 & 24.44 & 21.33 & .44 & 13.78 & 5.78 & 3.56 \\
\hline
\end{tabular}

Table 15. Descriptive statistics and mean differences for average occurrence of particular answers (codes) for light verbs (Mexicans vs. Croats).

\begin{tabular}{|c|c|c|c|c|c|c|}
\hline & & $N$ & Mean & Std. Deviation & $t$-test & $\underline{p}$ \\
\hline$A L I G \_T O P$ & Croats & 47 & .3002 & .22572 & \multirow{2}{*}{.128} & \multirow{2}{*}{$>.01$} \\
\hline & Mexicans & 25 & .2933 & .20000 & & \\
\hline$A L I G \_L X$ & Croats & 47 & .0142 & .04406 & \multirow{2}{*}{-.308} & \multirow{2}{*}{$>.01$} \\
\hline & Mexicans & 25 & .0178 & .05251 & & \\
\hline ALIG_CMP & Croats & 47 & .2175 & .25690 & \multirow{2}{*}{-.440} & \multirow{2}{*}{$>.01$} \\
\hline & Mexicans & 25 & .2444 & .22906 & & \\
\hline$A L I G \_P P H$ & Croats & 47 & .2648 & .21178 & \multirow{2}{*}{.988} & \multirow{2}{*}{$>.01$} \\
\hline & Mexicans & 25 & .2133 & .20767 & & \\
\hline$A L I G \_O P P$ & Croats & 47 & .0095 & .03134 & \multirow{2}{*}{.709} & \multirow{2}{*}{$>.01$} \\
\hline & Mexicans & 25 & .0044 & .02222 & & \\
\hline$A L I G \_M I S$ & Croats & 47 & .1631 & .16521 & \multirow{2}{*}{.633} & \multirow{2}{*}{$>.01$} \\
\hline & Mexicans & 25 & .1378 & .15476 & & \\
\hline ALIG_CTX & Croats & 47 & .0378 & .09347 & \multirow{2}{*}{-.766} & \multirow{2}{*}{$>.01$} \\
\hline & Mexicans & 25 & .0578 & .12472 & & \\
\hline ALIG_LXD & Croats & 47 & .0024 & .01621 & \multirow{2}{*}{-1.503} & \multirow{2}{*}{$>.01$} \\
\hline & Mexicans & 25 & .0356 & .10981 & & \\
\hline
\end{tabular}

b) With heavy verbs with in, compositionality is significantly more frequent in the group of Croats, and lexical determination is significantly less frequent in the group of Croats than in the group of Mexicans (see Tables 16, 17 and 18).

Table 16. Average occurrence of particular answers (codes) for heavy verbs in the group of Croats.

\begin{tabular}{|l|l|r|l|r|r|r|r|r|r|}
\hline & & $\begin{array}{l}\text { AHEA_ } \\
\text { TOP }\end{array}$ & $\begin{array}{l}\text { AHEA_ } \\
\text { LX }\end{array}$ & $\begin{array}{l}\text { AHEA } \\
\text { CMP }\end{array}$ & $\begin{array}{l}\text { AHEA } \\
\text { PPH }\end{array}$ & $\begin{array}{l}\text { AHEA } \\
\text { OPP }\end{array}$ & $\begin{array}{l}\text { AHEA } \\
\text { MIS }\end{array}$ & $\begin{array}{l}\text { AHEA_ } \\
\text { CTX }\end{array}$ & $\begin{array}{l}\text { AHEA_ } \\
\text { LXD }\end{array}$ \\
\hline$N$ & Valid & 39 & 39 & 39 & 38 & 38 & 39 & 39 & 39 \\
\hline & Missing & 29 & 29 & 29 & 30 & 30 & 29 & 29 & 29 \\
\hline Mean & & .073 & .107 & .440 & .213 & .013 & .137 & .030 & .006 \\
\hline Mean \% & & 7.265 & 10.684 & 44.017 & 21.272 & 1.316 & 13.675 & 2.991 & .641 \\
\hline
\end{tabular}

Table 17. Average occurrence of particular answers (codes) for heavy verbs in the group of Mexicans.

\begin{tabular}{|l|l|r|r|r|r|r|r|r|r|}
\hline & & $\begin{array}{l}\text { AHEA } \\
\text { TOP }\end{array}$ & $\begin{array}{l}\text { AHEA- } \\
\text { LX }\end{array}$ & $\begin{array}{l}\text { AHEA_ } \\
\text { CMP }\end{array}$ & $\begin{array}{l}\text { AHEA } \\
\text { PPH }\end{array}$ & $\begin{array}{l}\text { AHEA } \\
\text { OPP }\end{array}$ & $\begin{array}{l}\text { AHEA } \\
\text { MIS }\end{array}$ & $\begin{array}{l}\text { AHEA_ } \\
\text { CTX }\end{array}$ & $\begin{array}{l}\text { AHEA } \\
\text { LXD }\end{array}$ \\
\hline$N$ & Valid & 20 & 20 & 20 & 20 & 20 & 20 & 20 & 20 \\
\hline & Missing & 12 & 12 & 12 & 12 & 12 & 12 & 12 & 12 \\
\hline Mean & & .0667 & .3125 & .2292 & .1708 & .0042 & .1583 & .0625 & .0000 \\
\hline Mean \% & & 6.67 & 31.25 & 22.92 & 17.08 & .42 & 15.83 & 6.25 & .00 \\
\hline
\end{tabular}


Table 18. Descriptive statistics and mean differences for average occurrence of particular answers (codes) for heavy verbs (Mexicans vs. Croats).

\begin{tabular}{|c|c|c|c|c|c|c|}
\hline & $H R \_M E X$ & $N$ & Mean & Std. Deviation & t-test & $p$ \\
\hline AHEA_TOP & Croats & 39 & .0726 & .09782 & \multirow{2}{*}{233} & \multirow{2}{*}{$>.01$} \\
\hline & Mexicans & 20 & .0667 & .08377 & & \\
\hline AHEA_LX & Croats & 39 & .1068 & 13238 & \multirow{2}{*}{-5.232} & \multirow{2}{*}{$<.01$} \\
\hline & Mexicans & 20 & .3125 & .16194 & & \\
\hline AHEA_CMP & Croats & 39 & .4402 & .25503 & \multirow{2}{*}{3.346} & \multirow{2}{*}{$<.01$} \\
\hline & Mexicans & 20 & .2292 & .16639 & & \\
\hline AHEA_PPH & Croats & 38 & .2127 & .20930 & \multirow{2}{*}{.770} & \multirow{2}{*}{$>.01$} \\
\hline & Mexicans & 20 & .1708 & .16987 & & \\
\hline AHEA_OPP & Croats & 38 & .0132 & .03079 & \multirow{2}{*}{1.193} & \multirow{2}{*}{$>.01$} \\
\hline & Mexicans & 20 & .0042 & .01863 & & \\
\hline AHEA_MIS & Croats & 39 & .1368 & .14369 & \multirow{2}{*}{-.541} & \multirow{2}{*}{$>.01$} \\
\hline & Mexicans & 20 & .1583 & .14784 & & \\
\hline AHEA_CTX & Croats & 39 & .0299 & .08862 & \multirow{2}{*}{-1.127} & \multirow{2}{*}{$>.01$} \\
\hline & Mexicans & 20 & .0625 & .13211 & & \\
\hline AHEA_LXD & Croats & 39 & .0064 & .02250 & \multirow{2}{*}{1.780} & \multirow{2}{*}{$>.01$} \\
\hline & Mexicans & 20 & .0000 & .00000 & & \\
\hline
\end{tabular}

\section{IV.2.3. Discussion and conclusions for semantic determination and L1}

If we compare the data for out, discriminating light and heavy verbs in the whole sample (see section IV.2.) with the data relating to the participants' L1, we can see that compositionality is again an important aspect of meaning construal. In the whole sample, compositionality was a significantly more predictable pattern in PVs with heavy verbs, whereas in the Croatian sample it is more frequent in the strategic construal of both light and heavy PVs (in comparison to the Mexican sample).

Furthermore, in the whole sample, lexical determination was found to be significantly more frequent with heavy PVs. However, the data comparing Croatian and Mexican samples show that lexical determination is significantly less frequent in the group of Croats than in the group of Mexicans.

As for the data for in, no significant differences between the two groups were found in the construal of light PVs, whereas the construal of heavy PVs shows the same tendencies that were found for the heavy PVs with out, i.e., compositionality is significantly more frequent and lexical determination significantly less frequent in the Croatian sample. 
The reason why no significant differences were found between the Croats and Mexicans in their strategic construal of light PVs with in could be attributed to the following two factors:

a) the particle in has proved to be generally less informative than out $^{9}$;

b) the schematicity of light verbs is less likely to lead to a more compositional meaning construal.

Thus, irrespective of potentially compositionality-biased L1 elements, such as the existence of meaningful verbal prefixes in Croatian, the vagueness of the verb and the non-informativeness of the particle make the composite whole equally "complex" for both groups. However, with heavy verbs with both in and out, and with light verbs with out, the Croatian participants seem to construct meaning differently. They tend to attend to both parts of the composite whole much more frequently than their Mexican counterparts and they rely less on the lexical part of the PV construction. What we wish to suggest is that one of the key factors affecting and shaping this kind of tendency in their strategic construal is the fact that the Croatian language exhibits duality in terms of how it expresses the core schema, i.e., it uses satellites in the form of prefixes, even though it often behaves like a verb-framed language such as Spanish. In the case of the strategic construal of PV constructions, Croatian prefixes functioning as satellites are likely to facilitate meaningful recognition of the role of particles in English. Even though various avoidance issues have been discussed in SLA research, typological similarities pertaining to the event structure between Slavic and Germanic languages seem to have been ignored.

\section{CONCLUSION}

As already proposed by Geld and Letica Krevelj (2011), it would be scientifically irresponsible to tackle the question of English PVs and their meaning construction in L2 without acknowledging at least two major groups of factors shaping the nature of their construal:

a) language-internal factors pertaining to L2 (light vs. heavy verbs, and the degree of informativeness of particles), and language-internal factors pertaining to both L1 and L2 (verb-framed vs. satellite-framed languages); 
b) language-external factors (general language proficiency, years of learning L2, and various aspects of the learning environment conducive to developing learning strategies, e.g. an early start and continuity in learning, etc.).

Even though this paper has dealt only with the first group of factors, we wish to conclude with the model offered by Geld and Letica Krevelj (2011: 164) (see Figure 2).

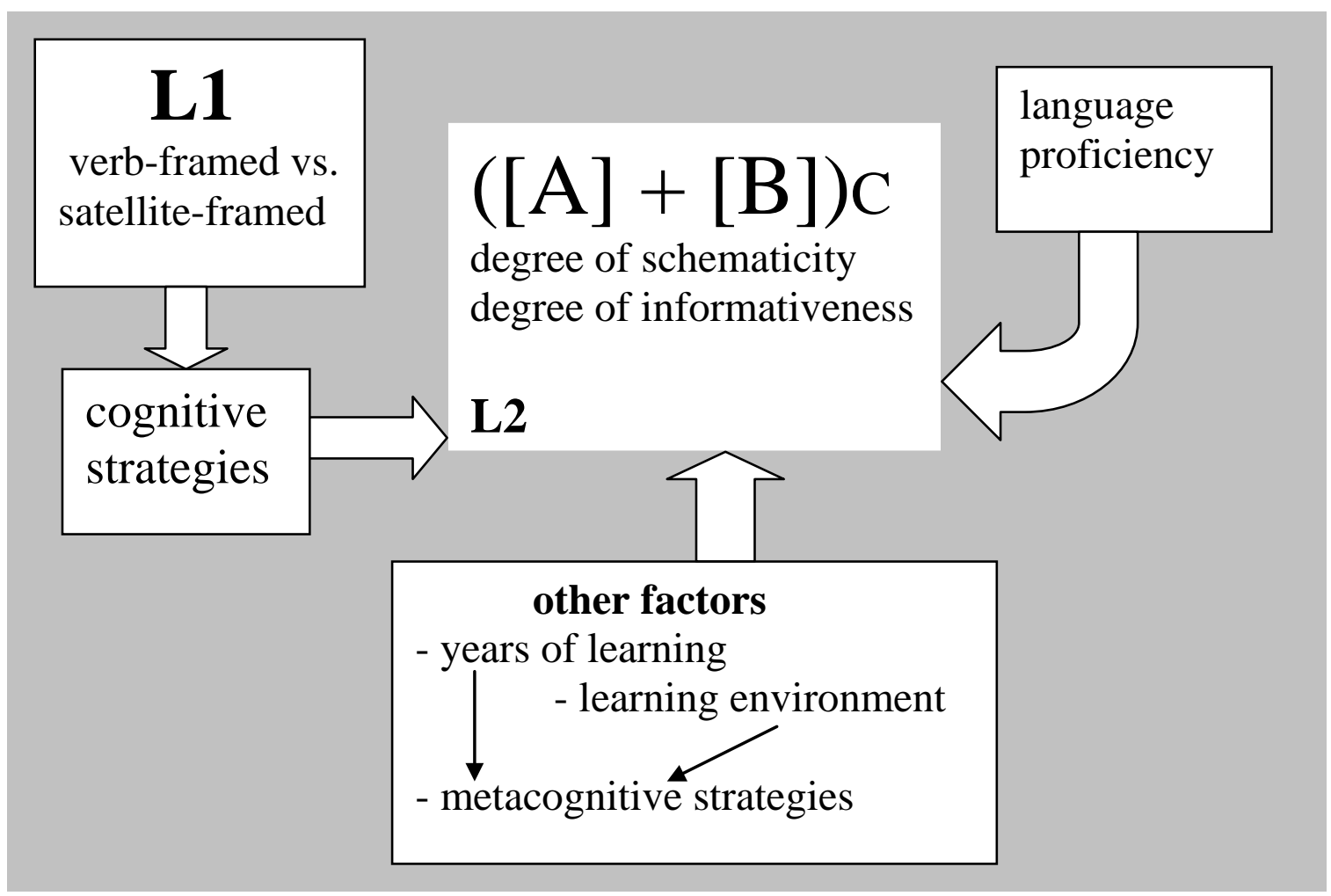

Figure 2. Factors affecting the strategic construal of particles in PV constructions (taken from Geld and Letica Krevelj 2011: 164).

In the middle of the model shown in Figure 2 there is a formula representing two component structures forming a composite whole (cf. Langacker 2000: 94). As stressed by Langacker, the composite structure (C) should not be taken as merely the union of $[A]$ and $[B]$, nor $[A]$ and $[B]$ as unmodified in (C). In our case, the formula represents PV constructions, and two aspects of component structures are singled out as important for this research: a) their degree of schematicity, and b) their degree of informativeness. But, in addition to the nature of the component structures, the construal of the composite whole in L2 is affected by the learners' L1, that is to say, their cognitive strategies in dealing with PV constructions are related to structures they encounter and use in their L1. Metaphorically speaking, the semantic battle between the particle and the verb will depend on what kind of structures are favoured in L1. Thus, for example, the users of 
Spanish as L1 are more likely to rely on verbs than on particles. However, the relationship between the two component structures and the overall meaning construal will also depend on language-external factors such as learners' language proficiency, their educational background, their age when they started learning English, the number of years of learning, the type of schools they attended, etc. In sum, meaning construal in L2 is tremendously complex and dynamic. Its exploration demands an approach encompassing multiple factors, especially when investigating highly idiomatic structures such as PVs.

\section{Notes}

1 See also Janda’s (1986) analysis of -za in Russian.

$\stackrel{2}{ }$ Croatian is certainly not a (proto)typical satellite-framed language. It actually exhibits both lexical and satellital strategies in expressing the core schema.

$\underline{3}$ In this paper, all schematic verbs will be called light verbs even though some are lighter than others and not all of them would be traditionally classified as light. Thus, the term light is used in a broader sense, and it is contrasted with heavy verbs, i.e., the verbs whose meaning is more specific and more transparent.

4 Hulstijn and Marchena replicated Dagut and Laufer's study. Thus, their results were entirely comparable.

$\underline{5}$ The etymology of the verbs was checked in both learner corpora using the online version of the Oxford English Dictionary (OED) (ibid.: 84).

$\underline{6}$ The data were independently validated by a linguist and a non-linguist validator. Their judgements were processed and compared to the author's, and the results did not show any significant differences.

${ }^{7}$ The terms topology and topological determination are used (metaphorically and metonymically) to denote all the cases where the meaning of the particle seems to override the meaning of the verb.

$\underline{8}$ The term "balanced determination" is identified here with the concept of compositionality inasmuch as it implies how closely an expression approximates the result predicted on the basis of particular component structures. By default, it is assumed that both components contribute to the semantic value of the composite whole.

$\stackrel{9}{9}$ See Geld and Maldonado this volume.

\section{REFERENCES}

Altenberg, B. and Granger, S. 2001. "The Grammatical and Lexical Patterning of MAKE in Native and Non-native Student Writing”. Applied Linguistics, 22 (2), 173-195.

Biber, D., Conrad, S. and Leech, G. 2002. Longman Student Grammar of Spoken and Written English. Harlow: Longman. 
Bolinger, D. 1971. The Phrasal Verb in English. Cambridge, Mass.: Harvard University Press.

Brinton, L. 1988. The Development of English Aspectual System. Cambridge: Cambridge University Press.

Bybee, J., Perkins, R. and Pagliuca, W. 1994. The Evolution of Grammar: Tense, Aspect and Modality. Chicago: Chicago University Press.

Cappelle, B. 2002. “And up it rises: Particle preposing in English”. In Dehé, N., R. Jackendoff, A. McIntyre and S.Urban (Eds.) Verb-Particle Explorations. Berlin/New York: Moton de Gruyter, 43-66.

Cappelle, B. 2005. Particle Patterns in English. Ph. D. dissertation, Katholieke Universiteit Leuven. Leuven.

Dagut, M. and Laufer, B. 1985. “Avoidance of phrasal verbs - a case for contrastive analysis”. Studies in Second Language Acquisition, 7, 73-80.

Dehé, N. 2002. Particle Verbs in English. Amsterdam/Philadelphia: John Benjamins.

Fraser, B. 1970. “Idioms within a transformational grammar". Foundations of Language, 6, 22-42.

Geld, R. and Letica Krevelj, S. 2011. "Centrality of space in the strategic construal of up in English particle verbs”. In Brdar, M., M. Omazić, G. Buljan, V. Bagarić and T. Gradečak-Erdeljić (Eds.) Space and Time in Language. Frankfurt/New York: Peter Lang Verlag, 145-166.

Gries, S.T. 1999. "Particle movement: A cognitive and functional approach”. Cognitive Linguistics, 10 (2), 105-145.

Hasselgren, A. 1994. "Lexical teddy bears and advanced learners: The study into the ways Norwegian students cope with English vocabulary”. International Journal of Applied Linguistics, 4, 237-60.

Heine, B., Claudi, U. and Hünnenmeyer, F. 1991. Grammaticalization: A Conceptual Framework. Chicago/London: University of Chicago Press. 
Heine, B., Guldemann, T., Kilian-Hatz, C., Lessau, D.A., Roberg, H., Schladt and Stolz, T. 1993. Conceptual Shift: A Lexicon of Grammaticalization Processes in African Languages. Köln: Institut for Arikanistik.

Hulstijn, J.H. and Marchena, E. 1989. “Avoidance. Grammatical or semantic causes?”. Studies in Second Language Acquisition, 11, 241-255.

Langacker, R.W. 1987. Foundations of Cognitive Grammar, vol. 1: Theoretical Prerequisites. Stanford: Stanford University Press.

Langacker, R.W. 2000. Grammar and Conceptualization. Berlin/New York: Mouton de Gruyter.

Lennon, P. 1996. “Getting 'easy verbs' wrong at the advanced level”. IRAL, 34 (1), 2336.

Liao, Y. and Fukuya, Y.J. 2004. "Avoidance of phrasal verbs: the case of Chinese learners of English”. Language Learning, 54 (2), 193-226.

Lindner, S.J. 1981. A Lexico-Semantic Analysis of English Verb Particle Constructions with OUT and UP. Ph. D. dissertation, University of California at San Diego.

Lipka, L. 1972. Semantic Structure and Word-Formation: Verb-Particle Constructions in Contemporary English. München: Fink.

McIntyre, A. 2002. "Idiosyncrasy in particle verbs”. In Dehé, N., R. Jackendoff, A. McIntyre and S. Urban (Eds.) Verb-Particle Explorations. Berlin/New York: Mouton de Gruyter, 95-119.

Newman, J. 1996. Give: A Cognitive-Linguistic Study. Berlin/New York: Mouton de Gruyter.

Newman, J. 1997. “Eating and drinking as sources of metaphor in English”. Cuadernos de Filología Inglesa, 6 (2), 23-231.

Newman, J. (Ed.) 1998. The Linguistics of Giving. Amsterdam/Philadelphia: John Benjamins.

Newman, J. 2004. Motivating the uses of basic verbs: Linguistic and extralinguistic consideration. In Radden, G. and K.-U. Panther (Eds.) Studies in Linguistic 
Motivation, Cognitive Linguistic Motivation 28. Berlin/New York: Mouton de Gruyter, 193-218.

Norvig, P. and Lakoff, G. 1987. “Taking: A study in lexical network theory”. In Aslo, J., N. Berry, L. Michaelis and H. Filip (Eds.) The Lexical Basis of Sentence Processing: Formal, Computational, and Experimental. Amsterdam and Philadelphia: John Benjamins, 325-346.

Quirk, R., Greenbaum, S., Leech, G. and Svartvik, J. 1985. A Comprehensive Grammar of the English Language. London: Longman.

Silić, J. and Pranjković, I. 2005. Gramatika Hhrvatskoga Jjezika [Croatian Grammar]. Zagreb: Školska knjiga.

Sinclair, J. 1991. Corpus, Concordance, Collocation. Oxford University Press: Oxford.

Svartvik, J. and Ekedahl, O. 1995. "Verbs in private and public speaking”. In Aarts, B. and C. Meyer (Eds.) The Verb in Contemporary English. Theory and Description. Cambridge: Cambridge University Press, 273-289.

Svorou, S. 1993. The Grammar of Space. Amsterdam/Philadelphia: John Benjamins.

Sweetser, E. 1990. From Etymology to Pragmatics. Cambridge: Cambridge University Press.

Tabakowska, E. 2003. “The preposition-prefix pair za(-) in Polish”. In Cuyckens, H., T. Berg, R. Dirven and K-U. Panther (Eds.) Motivation in Language, Studies in Honor of Günter Radden. Amsterdam/Philadelphia: John Benjamins, 153-178.

Talmy, L. 2000. Toward a Cognitive Semantics, vol. 1: Concept Structuring Systems. Cambridge, MA: MIT Press.

Viberg, Å. 1996. “Cross-linguistic lexicology. The case of English go and Swedish gå”. In Aijmer, K., B. Altenberg and M. Johansson (Eds.) Languages in Contrast. Lund: Lund University Press, 151-182.

Waibel, B. 2007. Phrasal Verbs in Learner English: A Corpus-Based Study of German and Italian Students. Ph. D. dissertation, University of Freiburg. 
Weinsberg, A. 1973. Przyimski Pprzestrzenne w Języku Polskim, Niemieckim i Rumuńskim [Spatial Prepositions in Polish, German and Romanian]. Wrocław: Ossolineum.

Wierzbicka, A. 1988. "Why can you have a Drink when you can't have an Eat". The Semantics of Grammar. Amsterdam/Philadelphia: John Benjamins, 293-357.

Received October 2011

Cite this article as:

Geld, R. 2011. “Topological vs. lexical determination in English particle verbs (PVs)”. Language Value, 3 (1), 49-75. Jaume I University ePress: Castelló, Spain. http://www.e-revistes.uji.es/languagevalue.

ISSN 1989-7103

Articles are copyrighted by their respective authors 